\title{
THE EFFECTS OF THE SHADOW ECONOMY ON THE LABOUR MARKET AND ITS REFLECTION ON THE RATE OF THE UNPLOYMENT
}

\author{
FatmaAtia, PhD \\ Department of Economics of Tanta University,A.R.E
}

Fatmaatia72@yahoo.com 


\title{
THE EFFECTS OF THE SHADOW ECONOMY ON THE LABOUR MARKET AND ITS REFLECTION ON THE RATE OF THE UNPLOYMENT
}

\begin{abstract}
-The objective of this paper is discusses the main drivers of the shadow economy are (in order): tax and social security burdens, tax morale, the quality of state institutions and labour market regulation. A reduction in the tax burden is therefore likely to lead to a reduction in the size of the shadow economy. Indeed, a virtuous circle can be created of lower tax rates, less shadow work, higher tax morale, a higher tax take and the opportunity for lower rates. Of course, a vicious circle in the other direction can also be created.

- Given this relationship, the high level of non-wage costs (averaging 39 per cent of total labour costs) and the penalty on individuals who move from earning one third to two thirds of the median wage .

-The effects of the shadow economy on the labour market and the relationship between the size of the shadow economy and unemployment.
\end{abstract}

\section{Keyword:}

Shadow economy - Unemployment - Labour market 


\section{الاقتصاد الذفى وأثثرة على سوق العمل و انعكاساته على معدلات البطلية}

\section{ملخص باللغة العربية:}

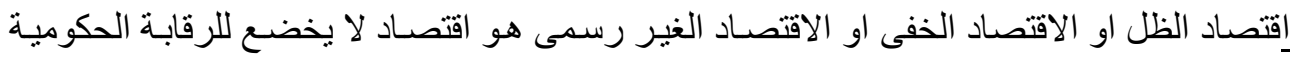

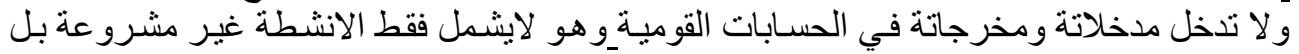

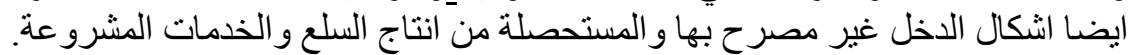

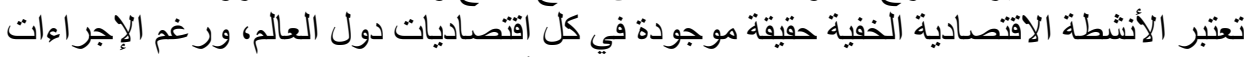

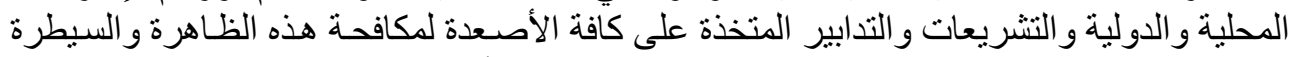

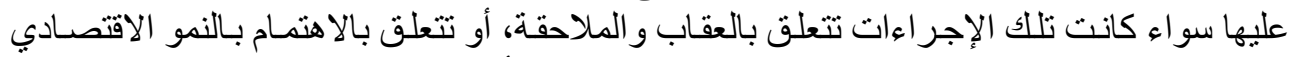

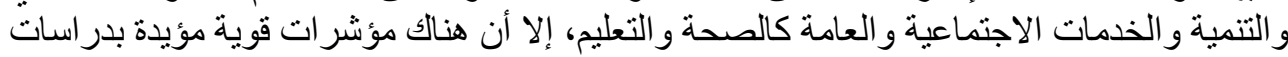

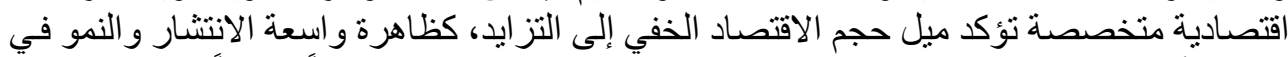

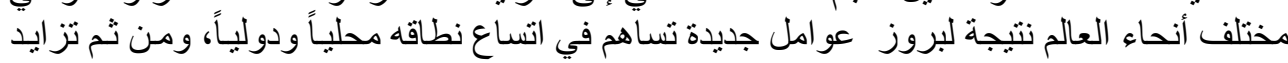

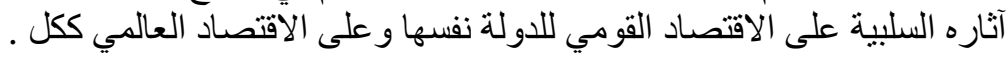

ونظراً إلى أن نشاط الاقتصاد الخفي غالباً ما يكون بعيداً عن سبطرة صـانع السياسـة الاقتصـادية

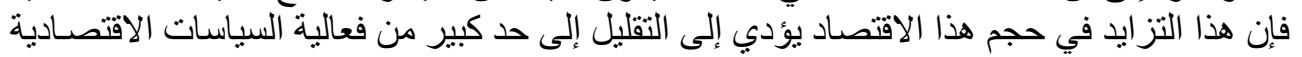

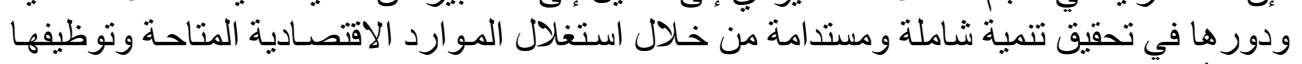
بشكل أمثل في مان.

ينعكس تصاعد أهمية الاقتصاد الخفي في شكل انخفاض معدلات مشـار كة قوة العمل، بالمقارنـة

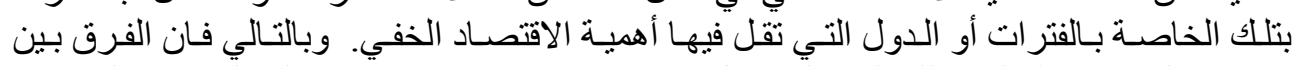

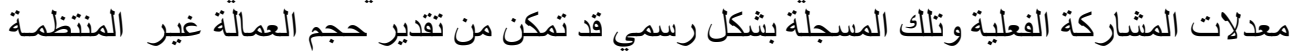
وبالتالي حجم الاقتصاد الخفي.

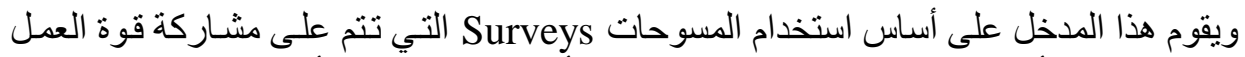

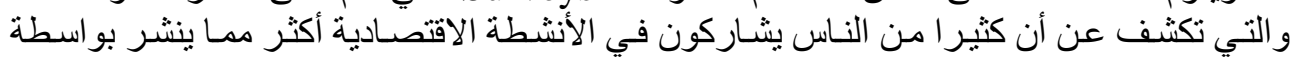

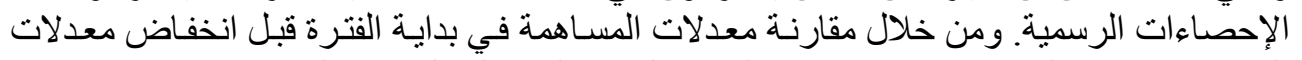

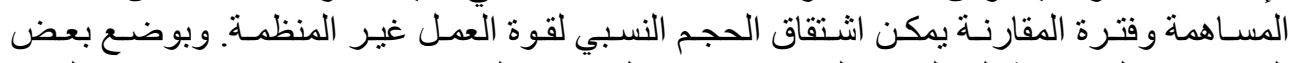
الفروض حول إنتاجية العامل في كل من الاقتصاد الرسمي والخفي يمكن تقدير حجم الاقتصاد الخفي بعلي

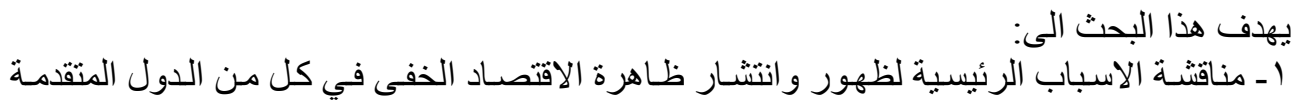

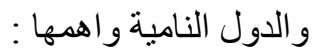
النظام الضريبى ـو اعباء الضمان الضران الاجتمـاعىـ حيث ان زيادة معدلات الضـر ائب تؤدى الى زيـادة

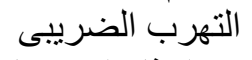
r ـ الاثار الاقتصادية للاقتصاد الخفى على سوق العمل ومعدلات البطالة و اثرة على معدلات الاجور 


\title{
THE EFFECTS OF THE SHADOW ECONOMY ON THE LABOUR MARKET AND ITS REFLECTION ON THE RATE OF THE UNPLOYMENT
}

\begin{abstract}
-The objective of this paper is discusses the main drivers of the shadow economy are (in order): taxand social security burdens, tax morale, the quality of state institutions and labour market regulation. A reduction in the tax burden is therefore likely to lead to a reduction in the size of the shadow economy. Indeed, a virtuous circle can be created of lower tax rates, less shadow work, higher tax morale, a higher tax take and the opportunity for lower rates. Of course, a vicious circle in the other direction can also be created.

- Given this relationship, the high level of non-wage costs (averaging 39 per cent of total labour costs) and the penalty on individuals who move from earning one third to two thirds of the median wage .

-The effects of the shadow economy on the labour market and the relationship between the size of the shadow economy and unemployment.
\end{abstract}

\section{Keyword:}

Shadow economy - Unemployment - Labour market

\section{INTRODUCTION}

Black, hidden, underground, unobserved, unrecorded, subterranean, informal, shadow, irregular, twilight, parallel. These are just a handful of the terms that have been used to describe economic activity which, for whatever reason, is not directly measured by any of the usual economic and fiscal indicators. The reasons for the existence, size, and growth of the hidden economy are many and varied, differing from country to country.

There is a widespread feeling that a substantial and increasing share of activities take place outside the official economy. This holds, in particular, for developing and transition but also for high 
income economies. Such activities are unrecorded by the system of national income accounting, which has become the accepted standard in all countries of the world.

The existence and increase of an underground economy gives rise to three major sets of concerns.

The economic and social conditions of individuals, household and countries are evaluated in a biased way if one relies on the official statistics. Thus, the official number of unemployed persons may hide that an (unknown) share of them actually work and receive wage income. As a consequence, the macro economic policies are likely to be too expansionary and social policy too excessive. A second concern is the loss of tax revenue as underground activities escape taxation.

A third concern interprets the underground economy as an indicator of an unhealthy state between citizens and government. The taxpayers are dissatisfied with what public services they get

for their contributions and seek to restores the balance by evading to the underground economy. It is feared that such reaction makes government unable to finance the public goods necessary for an economy and society.

A shadow economy of around 9-12 per cent of total economic activity is not untypical for Anglo-Saxon countries, and levels of 20 30 per cent are common in southern Europe. The size of the shadow economy has not varied dramatically over the last decade or so; if anything it has decreased slightly, at least until the outbreak of the euro crisis. The number of participants in the shadow economy is also very large: perhaps 30 million people in the $\mathrm{EU}$ alone.

Because of the relationship between the size of the shadow economy and the level of taxation, there is a danger of a vicious circle being created in certain circumstances. If the tax burden rises, we might get more shadow work, lower tax receipts, and then yet higher tax rates as the government tries to raise more revenue from a smaller tax base. This may cause yet further increases in the shadow economy, and so on. Of course, this vicious circle can be reversed and turned virtuous if the right policies are pursued. A further factor influencing 
the size of the shadow economy is 'tax morale'. If people think that the tax system is becoming less fair and that their neighbors are dodging tax, they are more likely to work in the shadow economy too. This can also contribute to the vicious and virtuous circle effects

There is also a very large shadow economy in many less developed countries. Here we use the less 'loaded' term 'informal economy' to describe this activity because its characteristics are different from the shadow economy in the West. The informal sector in poorer countries is typically between 25 and 40 per cent of national income and can represent up to 70 per cent of nonagricultural employment. In such countries, informal activity often arises because of the inadequacies of legal systems when it comes to formalising business registration rather than as a result of deliberate evasion activity. Nevertheless, the problems that informality can bring are enormous: it can be a serious constraint on business growth; and the lack of enforceability of business and employment contracts in a country makes prosperity much harder to achieve

In this paper:

1. discusses the definition of the shadow economy and also its measurement.

2. examine the main causes of shadow economic activity The impact of the shadow economy on the labour

3. market and the relationship between the size of the shadow economy and unemployment.

4. Finally, we consider various ways in which the shadow economy can be reduced.

\section{Literature Review and Definitions}

1-The phenomenon is known, and has been discussed in the literature, under many different names: informal, unofficial, irregular, parallel second underground, subterranean, hidden, invisible corded and shadow economy or moonlighting. In several languages the term most often used is black economy (le travail au noir, Schwarzarbeit, svarta sektor). 
No single definition exists but it depends on the purpose. The most precise and predominantly used definition seeks to relate the underground economy to officially measured national income:

It comprises all presently not recorded productive (i.e. value-adding) activities which should be in the national product (GNP). This definition allows to compare and to add the underground economy to GNP.

This definition excludes two major activities:

(a) Production that by convention is not part of GNP, in particular private household activities. The evaluation of its size has gendered a research area of its own. Depending on the approach and measurement technique, the household sector comprises between $30 \%$ and 50\% of GNP.

(b) Tax evasion is not value adding but redistributional and is therefore not included as such in the above definition (e.g. when taxes on interest payments are evaded). However, in general, no taxes are paid on underground activities (such as moonlighting for house building) which are value-adding. Thus, underground activities and tax evasion are related but certainly not identical. Tax evasion has also become a research area of its own. For the United States between 1973 and 1992 for example, it has been estimated that $17 \%$ of the taxes owned have been evaded.

The underground economy should neither be identified with illegality. Some activities are perfectly legal but are not subject to taxes (e.g. because of their small size), and therefore escape measurement in official statistics. Other activities are legal as such, but taxes are evaded.

Finally, on illegal activities (such as drug production and distribution) no taxes are paid. Broader definitions of the informal and underground economy, depending on their purpose, include private household production and redistribution activities. In the following, the more narrow definition considering on unrecorded productive activities will be focused on. P. Smith (1994:18) defines the shadow economy as 'market-based production of goods and services, whether legal or illegal, that escapes detection in the official estimates of GDP'. Put differently, one of the broadest definitions is: 'those economic activities and the income derived from them that circumvent or otherwise avoid government regulation, taxation or observation.( Adams, C. and P. Webley (2001), 
2-size of the shadow economies throughout the world:

Table(1) shows the average size of the shadow economy in different regions, as defined by the World Bank. The World Bank distinguishes eight world regions, which are: East Asia and Pacific; Europe (nonOECD) and Central Asia; Latin America and the Caribbean; Middle East and North Africa; high-income OECD;10 other high-income countries; South Asia; and sub-Saharan Africa.

If we consider the average size of the shadow economies of these regions weighted by total GDP in 2005, sub-Saharan Africa has the highest with 37.6 per cent, followed by Europe (non-OECD) and Central Asia with 36.4 per cent and Latin America and the Caribbean with 34.7 per cent. The lowest level of shadow economic activity is in high-income OECD countries with 13.4per cent. The average size of the shadow economy throughout the world, weighted by national income, is 17.1 per cent. The unweighted average is 33 per cent over the period 1999-2010.

table (1)

Average size of informal/shadow economy weighted by total GDP of 2010

\begin{tabular}{|l|c|c|c|c|c|}
\hline \multicolumn{1}{|c|}{ Region } & Mean & Median & Min & Max & $\begin{array}{c}\text { Standard } \\
\text { deviation }\end{array}$ \\
\hline \hline EAP East Asia and Pacific & 17.5 & 12.7 & 12.7 & 50.6 & 10.6 \\
\cline { 2 - 6 } & 36.4 & 32.6 & 18.1 & 65.5 & 8.4 \\
\hline $\begin{array}{l}\text { ECA Europe andCentral Asia } \\
\text { LAC Latin America and } \\
\text { the Caribbean }\end{array}$ & 34.7 & 33.8 & 19.3 & 66.1 & 7.9 \\
\hline $\begin{array}{l}\text { MENA Middle East and } \\
\text { North Africa }\end{array}$ & 27.3 & 33.8 & 19.3 & 66.1 & 7.7 \\
\hline $\begin{array}{l}\text { OECD } \\
\text { OHIE Other High- }\end{array}$ & 13.4 & 11.0 & 8.5 & 28.0 & 5.7 \\
\hline $\begin{array}{l}\text { Sncome } \\
\text { SAS South Asia }\end{array}$ & 20.8 & 19.4 & 12.4 & 33.4 & 4.9 \\
\hline $\begin{array}{l}\text { SSA Sub-Saharan Africa } \\
\text { World }\end{array}$ & 37.6 & 22.2 & 22.2 & 43.9 & 5.9 \\
\hline
\end{tabular}


It is worth noting that, in many parts of the world, the shadow economy is more or less endemic and is often described simply as 'informal' rather than 'shadow'. Such informal activity does not take place because individuals are deliberately avoiding paying taxes and avoiding abiding by regulation but because the infrastructure does not exist for the effective and efficient registration of businesses and to ensure the efficient collection of taxes. In many poorer countries, the shadow economy is not so much a problem of evasion by citizens but of an inability of people to pay taxes and register their activity even if they would wish to do so.( Alm, J. and B. Torgler (2006), )

Informal economic activity may also be tolerated to a high degree and in some sectors, such as agriculture, not even be regarded as

a policy issue. It follows from this that the policies that one might adopt to tackle the informal economy might be very different in countries where legal infrastructure is lacking compared with where the infrastructure exists but is deliberately - and illegally -ignored by those working in the shadow economy.

\section{2- The main drivers of the shadow economy:}

It is important to understand the main determinants of the shadow economy both because it informs policy in relation to dealing with the problem. The main causes relate to the level of taxes, regulation, public institutions and deterrence.

\section{$\underline{\text { Table }(2)}$}

Main causes of the increase of the shadow economy

\begin{tabular}{|l|c|c|}
\hline \multirow{2}{*}{\multicolumn{1}{|c||}{ Variable }} & \multicolumn{2}{c|}{$\begin{array}{c}\text { Influence on the shadow } \\
\text { economy (in \%)* }\end{array}$} \\
\cline { 2 - 3 } & (a) & (p) \\
\hline \hline 1-Tax and social security & $35-38$ & $45-52$ \\
\hline $\begin{array}{l}\text { 2contribution burdens Quality of state } \\
\text { institutions Labour }\end{array}$ & $10-12$ & $12-17$ \\
\hline 3-market regulation & $7-9$ & $7-9$ \\
\hline 4-Transfer payments & $5-7$ & $7-9$ \\
\hline 5-Public sector services & $4-7$ & $7-9$ \\
\hline 6-Tax morale & 22 & 25 \\
\hline 7-Influence of all factors & $84-98$ & $78-96$ \\
\hline
\end{tabular}


(a) Average values of 12 studies

(b) Average values of empirical results of 22 studies

*This is the normalized or standardized influence of the variable average over 12 studies (column a) and 22 studies (column b)

Source: Schneider (2009)

\section{- Summary of the main causes of the shadow economy:}

Table summarizes a number of empirical studies of the various factors influencing the shadow economy. The overview is based on the studies in which the size of the shadow economy is measured by the MIMIC or currency demand approach. As there is no firm evidence on the effect of deterrence using these approaches- at least with respect to the broad panel database on which this table draws - this variable is not included in the table. This is an obvious shortcoming of the studies, but one that cannot be addressed easily owing to the lack of internationally comparable data. In Table, two columns are presented showing the various factors influencing the shadow economy with and without the independent variable, 'tax morale'. This table clearly shows how an increase in tax and social security contribution burdens is by far the most important single determinant of the size of the shadow economy. This factor explains 35-38 per cent or 45-52 per cent of the variance of the shadow economy (depending on whether tax morale is included as an independent variable). Tax morale accounts for 22-25 per cent of the variance of the shadow economy.8 Quality of state institutions accounts for $10-12$ per cent and state regulation (mostly of the labour market) accounts for 7-9 per cent. Tax and social security contributions followed by tax morale and the intensity of state regulations are the major driving forces of the shadow economy. It is worth noting again that these different causes can interact with and reinforce each other. A higher shadow economy can reduce tax revenues and the quality of public services and state institutions; this can raise tax rates and also lower tax morale.( Feige, E. L. (ed.) (1989), ) 


\section{1--Relationships between TAXES AND the shadow economy:}

The paper by Allingham and Sandmo (1972) on income tax evasion present the Relationships between taxes and the shadow economy While the shadow economy and tax evasion are not congruent, activities in the shadow economy in most cases imply the evasion of direct or indirect taxes so that the factors affecting tax evasion will most certainly also affect the shadow economy. According to Allingham and Sandmo, tax compliance depends on its expected costs and benefits. The benefits of tax non-compliance result from the individual marginal tax rate that is avoided and the true individual income, including non-declared income. When we look at the shadow economy and its relationship with individual marginal tax rates, we calculate the overall marginal tax burden from indirect and direct taxes, including social security contributions. The individual income generated in the shadow economy is usually categorised as labour income though sometimes it may be capital income. The expected costs of non compliance derive from deterrence measures pursued by the state which determine the probability of detection and also the fines individuals face when they are caught. As individual morality also plays a role in compliance, additional costs could pertain beyond pure punishment by the tax administration in the form of psychic costs such as shame or regret. There may also be additional costs arising from, for example, a loss of reputation that may damage a business.

Kanniainen et al. (2004) incorporate many of these insightsin their model of the shadow economy by also considering labour supply decisions. They hypothesise that higher taxes unambiguously increase the shadow economy, while the effect of public goods financed by those taxes on the shadow economy depends on the ability to access public goods. Morality is also included in this analysis. The costs for individual non-compliers resulting from moral norms, however, appear to be mainly captured by state punishment, although selfesteem does play a role.

A shortcoming of these analyses is the possible endogeneity of tax morale and good governance. Tax morale is the phenomenon by which there is a greater tendency to declare income and pay taxes if taxpayers believe that the tax system is broadly fair, that others are 
paying their fair share, and so on. It is highly likely, of course, that good governance will increase tax morale. It is also possible that strong tax morale will create the conditions in which good governance is more likely to thrive. It might therefore be difficult to separate cause from effect.

\section{2--Tax and social security contribution burdens:}

Almost all studies find that tax and social security contribution levels are among the main causes of the shadow economy.4 Since taxes affect labour-leisure choices and increases labour supply to the shadow economy, the distortion of the overall tax burden is a major concern. The bigger the difference between the total labour cost in the official economy.( Bird, R. M. and E. M. Zolt (2008), )

\section{3-Public sector services and institutions:}

Better public services and institutions can reduce shadow economic activity. Furthermore, the interaction of public services with the effects of changes in tax rates can bring about dynamic effects. An increase in the shadow economy can lead to reduced government revenues which, in turn, can reduce the quality and quantity of government-provided goods and services. Ultimately, this can lead to an increase in tax rates for firms and individuals in the official sector as the government tries to raise more revenue, with the consequence of even stronger incentives to participate in the shadow economy. There is the possibility of a vicious circle developing here, with high tax rates increasing shadow economic activity, which reduces tax revenues and the quality of public services. This leads to higher tax rates, which encourage further increases in the shadow economy. Of course, a virtuous circle in the other direction can also develop if the right policies are put in plac.The quality of public institutions also plays a direct role in determining the size of the shadow economy.

The efficient application of tax systems and regulations by government play a crucial role in the decision to conduct undeclared work, and this may be even more important than the actual burden of taxes and regulations. 
In particular, corruption of bureaucracy and government ,while a good rule of law and secure property rights and contract enforceability increase the benefits of working in the formal sector. Olso Different forms of political and constitutional systems maybe more or less conducive to the growth of the shadow economy.

\section{3-THE IMPACT OFTHE SHADOW ECONOMY ON LABOUR MARKET}

To understand the shadow labour market, it is worth asking why people work in the shadow economy. In the official labour market, the costs that firms and individuals have to incur when hiring somebody are increased by the burden of tax and social insurance payments, as well as by regulation. In some countries, these costs are greater than the wage effectively earned by the worker - providing a strong incentive to work in the shadow economy. The underground use of labour may consist of a second job after (or even during) regular working hours. A second form is shadow economy work by individuals who do not participate in the official labour market. A third component is the employment of people such as illegal immigrants who are not allowed to work in the official economy. Empirical research on the shadow economy labour market is even more difficult than research on the value added in the whole shadow economy because it is difficult to determine how many hours an average shadow economy worker is actually working. Shadow economy work can involve anything from a full-time shadow economy job or self-employment without payment oftaxes to a few hours of child-minding or bar work every two or three weeks.

Reliable and consistent information on total non-wage costs is difficult to obtain and non-wage costs can vary depending on the level of pay, benefits being received and other factors. As such, averages do not necessarily indicate the incentives that are faced by specific groups when deciding to work in the shadow economy.

Nevertheless, Table3 shows non-wage costs for a selection of countries for people in the bottom half of the earnings 
$\underline{\text { Table ( 3) }}$

Non-wage costs, selected countries, for individuals in the bottom half of the earnings spectrum

\begin{tabular}{|l||c|c||}
\hline \multicolumn{1}{|c||}{ Country } & $\begin{array}{c}\text { Non-wage } \\
\text { costs, 2010 }\end{array}$ & $\begin{array}{c}\text { Low-wage trap for one } \\
\text { earnercouple with two } \\
\text { children, 2010 }\end{array}$ \\
\hline \hline Germany & $45 \%$ & $80 \%$ \\
\hline Sweden & $41 \%$ & $77 \%$ \\
\hline United Kingdom & $30 \%$ & $79 \%$ \\
\hline EU average & $39 \%$ & $58 \%$ \\
\hline USA & $28 \%$ & $68 \%$ \\
\hline Switzerland 18\% n/a & & \\
\hline
\end{tabular}

\section{Source:}

http://epp.eurostat.ec.europa.eu/statistics_explained/index. php?title=File:Tax_rate_indicators_on_low_wage_earners,_200 5_and_2010_(\%25).

Non-wage costs in this case are defined as income tax on gross wage earnings plus employee and employer social security contributions, expressed as a percentage of total labour costs. The measure therefore ignores costs of regulation and also value added tax, which might be relevant for sole traders in particular It is clear that there are very strong monetary incentives to work in the shadow economy. The detailed work on the labour supply decision suggests that this is important in explaining behavior. Lemieux et al. (1994) use microdata from a survey conducted in Quebec City in Canada. Their study provides economic insights regarding the size of the distortion caused by income tax and the welfare system. The results of this study suggest that hours worked in the shadow economy are responsive to changes in the net wage in the official sector. Indeed, the substitution between labour market activities in the formal and shadow sectors is high. These empirical findings indicate: 'participation rates and hours worked in the underground sector also tend to be inversely related to the number of hours worked in the regular sector' (ibid.: 235). These 
findings demonstrate a large negative elasticity of hours worked in the shadow economy with respect to the wage rate in the formal sector and also demonstrate high mobility between the sectors.

Kucera and Roncolato (2008: 321) also deal with informal employment. They address intensive labour market regulations as a major cause of informal employment and so-called 'voluntary' informal employment. The authors give a theoretical overview of both issues and also a survey of a number of empirical studies in which the effect of official labour market regulations on informal employment is analysed. They find a significant and quantitatively important influence. These issues will be discussed

\section{-The size of the informal labour force in Developing countries:}

The size of the informal labour force in African countries during the 2010s is shown in Table 4. Gambia had the largest informal economy labour force as a proportion of the official labour force at 80 per cent, followed by Guinea with 79 per cent, Benin with 77 per cent, Rwanda with 75 per cent and the Republic of Congo with 50 per cent.7 Zimbabwe had the lowest rate of informal work with 34 per cent of the official labour force. For African countries, the figures show considerable variation and should really be seen as preliminary results or indications of the real size of the informal sector. If it is assumed that the informal labour force is as productive as the official economy and contributes per capita a similar added value, the informal economy national income can be calculated, which is also shown in Table 4. On average, the supply official work in these 33 African countries was 54 per cent of the official labour force and 25 per cent of the population. 
$\underline{\text { Table } 4}$

Informal economy labour force in Africa, 2010

\begin{tabular}{|c|c|c|c|c|}
\hline country & million & $\begin{array}{l}\% \text { of } \\
\text { official } \\
\text { labour } \\
\text { force }\end{array}$ & $\begin{array}{c}\% \text { of } \\
\text { population }\end{array}$ & $\begin{array}{c}\text { Informal } \\
\text { national } \\
\text { income as \% o } \\
\text { official national } \\
\text { income } \\
\end{array}$ \\
\hline $\begin{array}{l}\text { Angola } \\
\text { Benin } \\
\text { Botswana } \\
\text { Burkina Faso } \\
\text { Cameroon } \\
\text { Chad } \\
\text { Congo } \\
\text { DEM.Rep.Congo } \\
\text { Gambia } \\
\text { Ghana } \\
\text { Guinea } \\
\text { Kenya } \\
\text { Lesotho } \\
\text { Liberia } \\
\text { Madagascar } \\
\text { Malawi } \\
\text { Mali } \\
\text { Mauritania } \\
\text { Namibia } \\
\text { Niger } \\
\text { Nigeria } \\
\text { Rwanda } \\
\text { Senegal } \\
\text { Sierra Leone } \\
\text { Sudan } \\
\text { Tanzania } \\
\text { Togo } \\
\text { Tunisia } \\
\text { Uganda } \\
\text { Zimbabwe }\end{array}$ & $\begin{array}{c}1.90 \\
2.000 .30 \\
3.40 \\
3.50 \\
1.30 \\
0.34 \\
.60 \\
3.40 \\
15.70 \\
15.70 \\
.30 \\
.50 \\
6.10 \\
2.62 \\
2.5 \\
6 \\
.31 \\
.40 \\
3.9 \\
2.5 \\
1.80 \\
.50 \\
, 33 \\
2.3 \\
23.4 \\
3.20 \\
2.5 \\
1.30 \\
4.6 \\
6.8 \\
.702 \\
5.8 \\
1.8 \\
3.9\end{array}$ & $\begin{array}{c}35.7 \\
76.9 \\
45 . \\
65 \\
61.7 \\
38 \\
50.3 \\
60.3 \\
80 \\
62 \\
58 \\
80 \\
72 \\
79 \\
40.8 \\
38.8 \\
35 \\
57.5 \\
51.7 \\
51 \\
48.9 \\
75 \\
62.4 \\
70 \\
42.6 \\
42.2 \\
38.9 \\
57.2 \\
56.4 \\
33.9 \\
54.2 \\
33.8 \\
56.2 \\
33.7 \\
54.2\end{array}$ & $\begin{array}{l}16.3 \\
34.5 \\
19.6 \\
32.5 \\
25.1 \\
18.2 \\
22.1 \\
23.9 \\
33.6 \\
26.3 \\
26.1 \\
42.4 \\
33.9 \\
37.6 \\
21 \\
15.4 \\
13.8 \\
27.6 \\
24.3 \\
17.5 \\
20.3 \\
23.5 \\
19.8 \\
40.4 \\
23.5 \\
28.4 \\
27.4 \\
16.3 \\
21.7 \\
16.1 \\
21.5 \\
28.5 \\
15.7 \\
15.9 \\
24.6\end{array}$ & $\begin{array}{c}16.2 \\
34.5 \\
19 \\
31.4 \\
24.5 \\
\mathrm{nLa} \\
21.8 \\
23.6 \\
32 \\
25.3 \\
\mathrm{n} / \mathrm{a} \\
41.5 \\
33 \\
36.9 \\
21.4 \\
15.4 \\
\mathrm{n} / \mathrm{a} \\
27.4 \\
23.8 \\
17.3 \\
20.5 \\
20.4 \\
\mathrm{n} / \mathrm{a} \\
48.8 \\
38.7 \\
27.6 \\
25.9 \\
16.3 \\
21.7 \\
16.1 \\
21.5 \\
\mathrm{n} / \mathrm{a} \\
15.7 \\
21.7 \\
15.7\end{array}$ \\
\hline
\end{tabular}


-Developing and transition countries - latest research There has been more recent work on the size and development of the informal economy labour force in developing and transition countries.8 For example, Kucera and Roncolato (2008: 321) deal with informal employment. They address issues of crucial importance to labour market policy. Informal employment in developing countries can be 'voluntary' in the same sense that it is voluntary in developed countries. In such cases, individuals

$\underline{\text { Table(5) }}$

Share of informal employment in total non-agricultural employment

\begin{tabular}{||l||c|c||c||}
\hline \multicolumn{1}{|c|}{ Region } & $1990-94$ & $1995-99$ & $2002-010$ \\
\hline $\begin{array}{l}\text { 22South and } \\
\text { Middle }\end{array}$ & 32.4 & 40.3 & 50.1 \\
\hline American countries & 60.4 & 65.4 & 70.2 \\
\hline \begin{tabular}{l} 
34 Asian countries \\
\hline $\begin{array}{l}42 \text { African } \\
\text { countries }\end{array}$
\end{tabular} & 55.9 & 47.1 & 52.4 \\
\hline $\begin{array}{l}21 \text { transition } \\
\text { countries }\end{array}$ & 32.2 & 46.9 & 60.5 \\
\hline
\end{tabular}

who have opportunities in formal labour markets may choose to work in the informal economy to avoid social security contributions and so on. Others, however, may work informally because of the difficulties - especially perhaps in rural areas - of formalizing employment relationships and registering businesses. The authors conclude that certain forms of labour market regulation cause informal employment, but do not suggest that all moves to reduce labour market regulation are necessarily beneficial. Table 5 shows the share of informal employment in total non-agricultural employment by region. The share of informal employment has increased over time. For example, the share of informal employment in South and Central American countries in the period 1985-89 was 32.4 per cent, and this had increased by the period 2000-2010 to 50.1 per cent. There were similar increases in Asia and Africa. It should be noted that these 
figures use total informal employment as the numerator (agricultural and non-agricultural) but only non-agricultural employment in the denominator

\section{3-THE SHADOW ECONOMY AND UNEMPLOYMENT}

Theoretical relationships between the shadow economy and unemployment .Although there has been some work to attempt to quantify the size of the shadow economy labour force and its causes, comparatively little attention has been given to the relationship between unemployment and working in the shadow economy. As Tanzi (1999) points out: 'the current literature does not cast much light on these relationships even though the existence of large underground activities would imply that one should look more deeply at what is happening in the labour market'

Bajada and Schneider (2009) examine the extent of participation in the shadow economy by the unemployed and investigate the relationship between the unemployment rate and the shadow economy. It is possible that those involved in the shadow economy are recorded as unemployed and therefore that true rates of unemployment are overstated. The literature on this topic has suggested, however, that the relationship between the shadow economy and unemployment is ambiguous. This is because those working in the shadow economy form a heterogeneous group of people - some will have other jobs; some will work in the shadow economy only for a few hours a week while claiming unemployment benefits; others may claim benefits while working many hours in the shadow economy; and so on. There are also various cyclical forces at work. Overall, the net effect is that the shadow economy is weakly correlated with unemployment. A model has been proposed by Bajada and Schneider for disentangling these effects. We can think of a 'substitution effect' which involves shadow economy work increasing with unemployment in the sense that shadow economy work acts as a substitute for the lack of formal employment available. The extent of this effect can be found by examining cyclical variations in unemployment. The model suggests that shadow economy work does typically increase during periods of declining legitimate economic activity (and therefore increasing unemployment) as shadow economy work replaces work in the formal economy. The relationship tends to be symmetrical in that, as 
unemployment increases, shadow work increases and, as unemployment decreases, shadow work also decreases. Indeed, as well as being similar in terms of sign, the relationships are also similar in terms of their magnitude for both increases and decreases in unemployment. It would appear, therefore, that the shadow economy acts as a source of financial support during periods of cyclical unemployment for those genuinely wanting to participate in the legitimate economy, although this does not exclude the possibility that long-term unemployed may also be participating in the shadow economy and that those with jobs may constitute the majority of those working in the shadow economy, even if the participation rate is higher among the unemployed. We might also expect unemployment support programs to affect shadow economic work. The analysis of various unemployment support programs across twelve OECD countries, however, does not appear to produce a strong systematic relationship between the generosity of social security systems and the nature of short-term shadow economic activity by the unemployed. Even the various benefit replacement rates across OECD countries appear to have little effect on the rate at which the unemployed take on or cut back shadow economy activity. Again, there are several potential effects that may be difficult to disentangle. A high replacement rate may make it less likely that somebody who is unemployed will take on shadow work to supplement their income. It may make it more likely, however, that they will remain unemployed and therefore in a position to supplement their benefit income illegally. Furthermore, ways in which the unemployment programs are managed will also affect the tendency for individuals to take on shadow work.( Chen, M. (2004), )On the whole Bajada and Schneider argue that dealing with the participation of the unemployed in the shadow economy is best handled by more stringent monitoring of those receiving unemployment benefits to reintegrate them into the workforce rather than by reducing benefit replacement rates. It is possible that a strategy of reducing replacement rates would lead to there being inadequate support for those experiencing financial hardship during periods of unemployment while having little impact on reducing participation by the unemployed who are willing and able to engage in shadow economy activity. This does, of course, depend 
on the pre-existing level of benefits. Perhaps the main lesson of the limited literature in this field, however, is that benefit levels should be determined by criteria other than their possible impact on the size of the shadow economy. -Policy implications: This evidence has important policy implications. It should be noted first that these patterns might well reflect existing policy A combination of strong work requirements and a relatively high level of insurance-based benefits would seem to provide the right incentives to reduce shadow economy work among the unemployed. At the same time, high marginal tax rates may well encourage shadow economy work among the employed In western and east-central Europe, undeclared work would seem to reinforce the marginalization of the unemployed given the low levels of remuneration the unemployed obtain from shadow work. At the same time, shadow work is prevalent among the unemployed. It would seem clear that some combination of targeting the unemployed with appropriate detection and deterrence measures and developing social insurance systems that provide incentives and assistance to return to work in the formal economy should be a priority. Such approaches can also be effective in reducing welfare fraud, including among people who have a job in the regular economy while claiming benefits. In addition, it is important that impediments to formal employment and the registering of self employed businesses are reduced. These issues will be discussed further below. These policy implications would appear to be particularly relevant to southern European countries given the high levels of shadow work undertaken by all the non-employed (including those who are not claiming welfare benefits)

-Tackling the shadow economy: broad policy approaches:

A first potential policy option is to 'do nothing' about the shadow economy. The rationale is that over half of all businesses start up operating in the shadow economy and that this sphere is therefore a principal seedbed for new enterprise creation, a breeding ground for the micro-enterprise system and a test bed for fledgling businesses (Williams, 2006) and should therefore be left alone. The problem, however, is that this hidden enterprise culture has negative impacts on legitimate businesses, those working in the shadow economy, their customers and governments. Legitimate businesses witness unfair 
competition from such enterprises, meaning that they end up paying higher taxes than would otherwise be the case and cannot compete on a level playing field with them (Evans et al., 2006; Renooy et al., 2004; Gallin, 2001; Grabiner, 2000; Williams and Windebank, 1998). Even if the reality is that their tax burden does not rise significantly as a result of shadow entrepreneurs, the affect on tax morale can be damaging. The tax system could come to be perceived as unfair.

At the same time, shadow entrepreneurs are unable to develop and grow owing to their inability to gain access to capital, advertise their business or secure support (Evans et al., 2006; Gallin, 2001; ILO, 2002). This is a particular problem in less developed countries. Customers of shadow enterprises, furthermore, find themselves without legal recourse if a poor job is done; without insurance cover; without guarantees in relation to the work conducted; and with no certainty that health and safety regulations have been followed. Those working for the shadow economy business encounter similar problems. Finally, governments witness a loss of revenue in terms of non-payment of taxes owed and, if a significant segment routinely engage in such endeavour, it may well encourage a more casual attitude towards the law more widely (Renooy et al., 2004; Williams, 2006). In sum, the negative impacts of doing nothing mean that actions to tackle the shadow economy are desirable.

\section{-Eradicating the shadow economy}

A second option is to stamp out the shadow economy. If we treat the shadow labour force as rational economic actors who evade tax because the pay-off is greater than the expected cost of being caught and punished (Allingham and Sandmo, 1972), the cost benefit ratio confronting those engaged in - or considering engaging in - shadow work could be changed by increasing the costs in the form of the perceived or actual likelihood of detection and the penalties and sanctions for those caught (e.g. Grabiner, 2000; Richardson and Sawyer, 2001). The major problem with such an eradication approach is that the shadow economy is a principal breeding ground and seed bed for entrepreneurship, so eradicating it will stamp out precisely the entrepreneurship and enterprise culture that is needed for economic development and growth (Small Business Council, 2004; Williams, 2006).

. A 'pull' approach could be used instead. Here, more enabling measures are adopted that make participating in the official economy easier and more beneficial. These enabling measures are of three kinds. Firstly, preventive measures can be pursued to deter new entrants into the shadow economy. Secondly, curative measures can be pursued to help those already participating in the shadow economy to transfer into the official realm. 


\section{Conclusion:}

1-The size of the shadow economy might have surprised some readers if they had seen these estimates two or three years ago. The evidence suggests, for example, that the shadow economy constitutes around 20 per cent of national income in Italy, Spain

and Greece. The recent euro crisis, however, has shone a spotlight on problems in these countries with regard to tax collection and compliance and the problems are now more widely known

2-The causes of the shadow economy include tax and social security burdens, tax morale, the quality of state institutions, labour market regulation, the level of transfer payments and the quality of public services. The first two in this list are empirically substantially more important than the others

3-The level of shadow economic activity does not necessarily cause direct reductions in economic welfare. Economic activity is, after all, economic activity. Whether it is declared or not it still raises people's incomes. The money earned in the shadow economy is often immediately spent in the formal economy

4-Measuring the shadow economy is extremely difficult. Nevertheless, it is possible using modern statistical techniques to estimate its size with a reasonable degree of confidence.

5- There is an extremely high level of shadow work in less developed countries. The nature of what is better described as 'informal' work in this context, however, is very different from that in OECD countries. In general, the problems lie with the legal systems that make it difficult for businesses and individuals to register their activity. Indeed, in some sectors, informality in business and employment relationships can effectively become the norm. The main focus of our detailed discussion and policy recommendations relates to the OECD. Though we have presented an analysis of the extent of the informal economy in less developed countries, we do not take this further. 


\section{Recommendations}

The shadow economy is more pervasive than is perhaps widely thought, its measurement is difficult and successful policy solutions are not always easy to implement. This monograph, however, has suggested how to turn the tide. It is necessary to have high tax morale combined with a tax system that is coherent and works with - rather than against - the grain of human nature. This relates not just to the size of the tax burden but to the particular incentives that apply to specific groups within society when they undertake more work or earn more money. In addition, a range of more detailed policy approaches can be taken. In many senses these 'micro-measures' are 'win-win' policies in that they cost relatively little money and just involve ensuring that there is a sensible regulatory and legal framework within which business should operate. If this monograph starts to encourage governments to adopt such approaches, then it will have achieved 


\section{Reference:}

1-Adams, C. and P. Webley (2001), 'Small business owners'attitudes on VAT compliance in the UK', Journal of Economic Psychology, 22(2): 195-216.

2-Alm, J. and B. Torgler (2006), 'Culture differences and tax morale in the United States and in Europe', Journal of Economic Psychology, 27(2): 224-46.

3-Andreoni, J., B. Erard and J. Feinstein (1998), 'Tax compliance', Journal of Economic Literature, 36(4): 818-60

4-.Bartlett, B. (1998), 'Corruption, the Underground Economy, and Taxation', unpublished manuscript, National Center for Policy nalysis, Washington, DC.

5-Bird, R. M. and E. M. Zolt (2008), 'Tax policy in emerging countries', Environment and Planning C, 26(1): 73-86.

6-Charmes, J. (2000), 'Informal sector poverty and gender, a review of the empirical evidence', paper prepared on behalf of Wiego (Women in Informal Employment: Globalizing and Organizing), Washington, DC, and Paris: OECD and World

Bank.

7-Chen, M. (2004), 'Rethinking the informal economy: linkages with the formal economy and the formal regulatory environment', paper resented at the EGDI-WIDR conference 'Unleashing human potential: linking the informal and formal sectors', Helsinki, Finland.

8-Davis, J. S., G. Hecht and J. D. Perkins (2003), 'Social behaviors, enforcement and tax compliance dynamics', Accounting Review, 78(1): 39-69.

9-Feige, E. L. (ed.) (1989), The Underground Economies. Tax Evasion and Information Distortion, Cambridge: Cambridge University 